\title{
Comparative study on efficacy of two Ayurvedic formulations by stress induced gastric ulcers and hypothermia
}

\section{Research article}

\author{
Baragi Pramod $\mathrm{C}^{1^{*}}$, Patgiri B J $\mathbf{2}^{2}$, Prajapati $\mathbf{P} \mathrm{K}^{3}$, Ravishankar $\mathbf{B}^{4}$, Baragi Umapati $\mathrm{C}^{5}$ \\ 1. Associate Professor, Dept. of RS \& BK, NKKJAMC and Post Graduate Centre, Bidar \\ 2. Reader, 3. Prof. and H. O. D, Dept. of RS \& BK, IPGT \& RA, GAU, Jamnagar \\ 4. Director, S.D.M. Research Centre for Ayurveda and Allied Sciences, Udupi \\ 5. Assistant Professor, Dept. of Basic Principles, SDM College of Ayurveda, Udupi
}

\begin{abstract}
Gastric disorders like hyperacidity and ulcers are a common clinical entity. A rational therapy for gastric ulcers still remains elusive and search for safer potential drugs is being carried out. The present comparative experimental study was planned to see the efficacy of two Ayurvedic formulations i.e. Narikela Khanda (Cocus nucifera candy) and Narikela Khanda granules by using swimming stress induced ulcers and hypothermia in albino rats. Wister strain albino rats of either sex were divided into three groups, each group consists of six animals. Here group 'A' received Narikela Khanda suspension, while group 'B' received Narikela Khanda granules suspension and group ' $\mathrm{C}$ ' received dose of tap water which served as stress control group. Narikela Khanda and Narikela Khanda granules were prepared in house laboratory of the department. Wister strain albino rats of either sex weighing between 150-250g were selected for the study. Effects of both the formulations were assessed on different parameters like change in body weight, effect on rectal temperature and ulcer index. Body weight decrease was seen in both the formulations compared to initial body weight. Both the formulations did not affect the rectal temperature to significant extent in comparison to stress control group. An apparent and statistically highly significant decrease in ulcer index was observed in both the test formulations treated group in comparison to stress control group. The magnitude of anti-ulcer effect was found to be higher in Narikela Khanda granules treated group.
\end{abstract}

Keywords: Narikela Khanda, Narikela Khanda granules, Gastric ulcer, Swimming stress, Anti-ulcer activity.

*Corresponding Author:

Pramod C. Baragi, Associate Professor,

Dept. of Rasashastra and Bhaishajya Kalpana,

N. K. Jabshetty Ayurved Medical College and Post Graduate Centre,

Gumpa, Manalli Road,

Bidar (Karnataka).

E-mail ayupramod@yahoo.co.in

Mobile- 09886298976

\section{Introduction:}

New formulation cannot be administered in human beings without proper preparation, subjecting to chemical analysis and experimental studies on the lower animals. Once it is assessed as safe then only it can be given to human beings. So the aim of present pharmacology study in animals is to study the effects of the test drugs and also to access any side effects in them.

Hyperacidity and ulcers are a common clinical entity. These are major 
health problem with multifunctional etiology. The development of gastric ulcers occurs with acid and the breakdown of mucosal defense. Local mechanisms implicated in mucosal defense are mucous like alkaline secretions, mucosal hydrophilic activity, rapid epithelial cell renewal, rich mucosal blood flow and increased resistance of gland cells in deep mucosa to acid and peptic activity.(1)

A rational therapy for gastric ulcers still remains elusive and search for safer potential drugs is being carried out. Use of natural drugs in gastric ulcers is well documented. Most of these drugs augment the mucosal defensive factors, which are thought to be important for protection of gastric mucosa.(2) (3)

Narikela (Cocus nucifera Linn.) is commonly available fruit. Many preparations are described in classical texts of Ayurveda. Narikela Khanda was prepared as per the reference of Bhaishajya Ratnavali (Shularogadhikara) and Narikela Khanda granule was prepared from the same formulation in the form of granules to enhance the stability. It is popularly used to treat Amlapitta (hyperacidity).(4) Hence, the present comparative experimental study is planned to see the efficacy of these Ayurvedic formulations i.e. Narikela Khanda and Narikela Khanda granules by using swimming stress induced ulcers and hypothermia in albino rats.

\section{Material and methods:}

\section{Test formulations:}

\section{Preparation of Narikela Khanda -}

Narikela Khanda was prepared in house laboratory of the department, with following all aseptic measures. Here fresh coconut was broken and water and pulp are collected in separate vessels. The pulp was transformed into paste form and then fried with ghee till ghee starts to separate from paste. The coconut water is filtered with a sieve and Khanda Sharkara (sugar candy) was added to it and then kept on
Mandagni for preparing Paka. When Paka Siddhi Lakshanas are seen the fried pulp was added and then the Prakshepaka Dravyas like Dhanyaka, Pippali, Musta, Vamsalochana, Shweta Jiraka, Krishna Jiraka, Twak, Ela, Tejapatra, Nagakeshara are added and mixed thoroughly and stored in air tight pet bottles.

\section{Preparation of Narikela Khanda Granules -}

The same above preparation when it is still hot, granules are prepared by pressing the bolus mass in 10 no. mesh and are dried at room temperature. After completely self cooled and dried it is carefully collected in air tight pet bottles.

Animals: Wistar strain albino rats of either sex weighing between 150-250g were selected for the study from the animal house attached to the institute. They were housed at $22 \pm 2^{\circ} \mathrm{C}$ with constant humidity $50-60 \%$, on a $12 \mathrm{~h}$ natural day and night cycles. They were fed with diet Amrut brand rat pellet feed supplied by Pranav Agro Industries and tap water ad libitum. The experiments were carried out in accordance with the directions of the Institutional Animal Ethical Committee (IAEC).

Dose selection \& schedule: The dose of the trial drugs were calculated by extrapolating the human dose to animals based on the body surface area ratio by referring to the standard table of Paget \& Barnes.(5) The test drugs were suspended in tap water and administered orally at morning hours.

Route of administration: Oral route was selected for the administration of drug to respective group of animals through gastric catheter sleeved to a syringe.

Drug administration schedule: The test drug and vehicles were administered daily morning between 8am to 10am IST. 
Statistical analysis: The results are presented as Mean \pm SEM. The data generated during the study were subjected to student's ' $t$ ' test for unpaired data to assess the statistical significance. The values were considered significant at the levels of $\mathrm{P}<0.05, \mathrm{P}<0.01$ and $\mathrm{P}<0.001$.

\section{Experimental procedure:}

Stress-induced hypothermia was performed as described by Seth et al.(6) Eighteen rats weighing between 150-250 g were selected for the study and divided into three groups of six animals each viz. $\mathrm{A}, \mathrm{B}$ and $\mathrm{C}$.

- $\quad$ Group ' $A$ ' - The rats in group ' $\mathrm{A}$ ' received Narikela Khanda suspension in a dose of $1.1 \mathrm{~g} / \mathrm{kg}$ body weight.

- Group 'B'- The rats in group 'B' received Narikela Khanda granules suspension in a dose of $1.1 \mathrm{gm} / \mathrm{kg}$ body weight.

- Group ' $C$ '- The rats in group ' $C$ ' received dose of tap water and served as stress control group.

The rats were kept in individual metabolic cages to prevent coprophagy and fasted for $12 \mathrm{~h}$ with access to water ad libitum. On seventh day one hour after drug administration, the initial rectal temperature of individual rats is noted. After noting initial rectal temperature, rats are kept inside specially arranged containers which were made up of plexiglass with holed lids. The water level is maintained up to $25 \mathrm{~cm}$ height and temperature of water is maintained at $25 \pm$ $2{ }^{\circ} \mathrm{C}$. Rats placed in container and exactly after 20 minutes of exposure to stressed condition, the rats are taken out individually and final rectal temperature of each rat is noted. The drop in temperature is noted down.

Stress induced ulcer developed by method as described by Parmar et al.(7) and modified according to experimental need. The rats, after noting their final rectal temperature as explained above, were again exposed to the swimming stress inside the same container. At the end of 14 $\mathrm{h}$ period the body weight of each rat is noted and rats were sacrificed by cervical dislocation. The stomach is then dissected and opened along the greater curvature and the inner surface gently washed and examined with magnifying lens for ulceration in glandular area as well as in rumen (if any) to determine the severity of ulcer and ulcer index is calculated.(8)

\section{Reagents and chemicals:}

All reagent and chemicals used for the study were of analytical grade.

\section{Results:}

Body weight decrease was observed in all the three groups, in comparison to initial body weight. The magnitude in loss of body weight in both the treated group is less in comparison to stress control group. However, this difference in the body weight gain was found to be statistically non-significant (Table - 1). The test drug administration did not affect the rectal temperature to significant extent in comparison to stress control group (Table - 2).

An apparent and statistically highly significant decrease in ulcer index was observed in both the test formulations treated group in comparison to stress control group. The magnitude of anti-ulcer effect was found to be higher in Narikela Khanda granules treated group (Table - 3). 
Table - 1: Effect on body weight:

\begin{tabular}{|l|l|l|l|l|l|}
\hline Group & $\begin{array}{l}\text { Dose } \\
(\mathbf{g} / \mathbf{k g})\end{array}$ & $\begin{array}{l}\text { Initial body } \\
\text { weight } \\
(\mathbf{g})\end{array}$ & $\begin{array}{l}\text { Final body } \\
\text { weight } \\
\text { (g) }\end{array}$ & $\begin{array}{l}\text { Actual change } \\
\text { (Loss) } \\
(\mathbf{g})\end{array}$ & $\begin{array}{l}\text { \% } \\
\text { change } \\
\text { in body } \\
\text { weight }\end{array}$ \\
\hline $\begin{array}{l}\text { Narikela } \\
\text { Khanda } \\
(\mathbf{A})\end{array}$ & 1.1 & $282.50 \pm 20.56$ & $272.50 \pm 22.87$ & $12.00 \pm 03.74$ & 41.54 \\
\hline $\begin{array}{l}\text { Narikela } \\
\text { Khanda } \\
\text { granules } \\
\text { (B) }\end{array}$ & 1.1 & $242.00 \pm 11.58$ & $231.60 \pm 08.98$ & $15.33 \pm 02.10$ & 30.05 \\
\hline $\begin{array}{l}\text { Stress water } \\
\text { control } \\
\text { (C) }\end{array}$ & Q. S. & $236.00 \pm 12.08$ & $202.00 \pm 05.83$ & $20.00 \pm 03.16$ & ------ \\
\hline
\end{tabular}

Data: Mean \pm SEM

Table - 2: Effect on rectal temperature:

\begin{tabular}{|c|c|c|c|c|c|}
\hline Group & $\begin{array}{l}\text { Dose } \\
(\mathrm{gm} / \mathrm{kg})\end{array}$ & $\begin{array}{l}\text { Initial rectal } \\
\text { temp. }\left({ }^{\circ} \mathrm{C}\right)\end{array}$ & $\begin{array}{l}\text { Final rectal } \\
\text { temp. }\left({ }^{\circ} \mathrm{C}\right) \\
\text { (after 20min. } \\
\text { swimming) }\end{array}$ & $\begin{array}{l}\text { Actual } \\
\text { change i } \\
\text { rectal } \\
\text { temp. }\end{array}$ & $\begin{array}{l}\% \text { change in } \\
\text { rectal temp. }\end{array}$ \\
\hline $\begin{array}{l}\text { Narikela } \\
\text { Khanda } \\
\text { (A) }\end{array}$ & 1.1 & $37.10 \pm 00.72$ & $29.76 \pm 00.68$ & $\begin{array}{l}07.34 \\
00.77\end{array}$ & $19.71 \pm 01.92$ \\
\hline $\begin{array}{l}\text { Narikela } \\
\text { Khanda } \\
\text { granules } \\
\text { (B) } \\
\end{array}$ & 1.1 & $37.88 \pm 00.23$ & $30.10 \pm 00.83$ & $\begin{array}{l}07.78 \\
00.62\end{array}$ & $20.60 \pm 01.76$ \\
\hline $\begin{array}{l}\text { Stress } \\
\text { water } \\
\text { control } \\
\text { (C) }\end{array}$ & Q. S. & $37.18 \pm 00.29$ & $30.20 \pm 00.41$ & $\begin{array}{l}06.87 \\
00.19\end{array}$ & $18.83 \pm 00.47$ \\
\hline
\end{tabular}

Data: Mean \pm SEM

Table - 3: Effect on ulcer index:

\begin{tabular}{|l|l|l|l|}
\hline Group & $\begin{array}{l}\text { Dose } \\
(\mathbf{g} / \mathbf{k g})\end{array}$ & Ulcer index & $\begin{array}{l}\text { \% change } \\
\text { in ulcer } \\
\text { index }\end{array}$ \\
\hline $\begin{array}{l}\text { Narikela Khanda } \\
(\text { A) }\end{array}$ & 1.1 & $01.27 \pm 00.26^{* *}$ & $62.00 \downarrow$ \\
\hline $\begin{array}{l}\text { Narikela Khanda granules } \\
\text { (B) }\end{array}$ & 1.1 & $00.97 \pm 00.22^{* * *}$ & $70.00 \downarrow$ \\
\hline $\begin{array}{l}\text { Stress water control } \\
\text { (C) }\end{array}$ & Q. S. & $03.30 \pm 00.51$ & --- \\
\hline
\end{tabular}

Data: Mean \pm SEM $\quad * * \mathrm{P}<0.01 \quad * * * \mathrm{P}<0.001$ 


\section{Discussion:}

Narikela Khanda is a compound herbal formulation which is indicated in treatment of Amlapitta. Narikela (Cocus nucifera Linn.) is a major component of this formulation. Formulation factors also play important role in the therapeutic acceptance of a putative drug. Many factors are required to be taken in to consideration while formulating like patient acceptability, impact of formulation on pharmacokinetics and pharmacodynamics. Narikela Khanda, as mentioned above, is indicated in classics for the treatment of Amlapitta which can be roughly equated with hyperacidity related disorders. Our team was interested to make it more patient friendly hence it was thought worthwhile to explore the possibility of administering the Narikela Khanda in the form of granules. As it is a well known fact that converting the raw drugs in to any formulation influences the efficacy of a test drug. So, the study was undertaken to compare the pharmacological evaluation to ascertain whether administration of Narikela Khanda in granules form lead to change in pharmacological activity or not.

The similarity in etiology, histology and clinical management between experimental stress ulcers and clinical stress ulcers, enables the use of animal stress ulcer models as an experimental tools for stress induced gastric bleeding and ulceration.(9)

Various physical and psychological stresses cause gastric ulceration in humans and experimental animals (10). The precise biochemical changes during ulcer generation are not clear yet, although various hypotheses have been proposed from time to time. Stress induced ulcers are probably caused by the release of histamine, by enhanced acid secretion and reduction in mucus production(11) increased gastric motility(12) vagal over activity(13), reduction in mucosal blood flow and peripheral neural influences(14) mast cell degranulation(15) and decreased prostaglandins level.(16)

1. Effect on body weight: All the three groups show an apparent decrease in body weight in comparison to initial body weight. However the magnitude in loss of body weight in both the treated group is less in comparison to stress control group (Table-1).

2. Effect on rectal temperature: Reduction in rectal temperature (hypothermia) was observed in rats subjected to forced swimming stress for 20 minutes. Drugs which are having adaptogenic properties will reverse the hypothermia in stress conditions. In present study the data on the effect on forced swimming induced hypothermia reveals that the test formulations did not affect the rectal temperature in comparison to stress control group. So it is evident that the test drug has no effect on stress induced hypothermia. Another point which should be noted is that different set of factors modulate stress hypothermia which is an acute response and stress induced ulceration. Since the first one is not affected it can be suggested that the factors modulating stress hypothermia are not influenced by the test formulations (Table2).

3. Effect on ulcer index: In contrast to the effect observed on pyloric ligation induced gastric ulcer, in stress ulcers the test formulations showed apparent and statistically highly significant decrease in ulcer index in comparison to stress control group. This indicates that the formulations given under optimal conditions and in suitable form may be effective in stress ulcers. In Narikela Khanda there was $62 \%$ decrease and in Narikela Khanda granules it was $70 \%$ decrease in ulcer index. The effect indicates the presence of anti-stress (adaptogenic) effect in the test formulations (Table-3). 
Several mechanism have been proposed to explain the occurrence of gastric erosion during stressful condition, among the important aetiopathological factors is ischaemia of the gastric mucosa leading to disruption of acid from gastric lumen to gastric mucosal tissue. Stress of any kind stimulates ACTH release by stimulating hypothalamic pituitary adrenal (HPA) axis mainly through release of corticotrophin releasing hormone (CRH) from the neurons of the para-ventricular nuclei of the hypothalamus. CRH is reported stimulate cyclic AMP production and regulate intracellular entry of $\mathrm{Ca}^{++}$and increase the level of pro-opiomelanocortin (POMC) the precursor molecule necessary for the formation of ACTH. This effect is believed to be through stimulation of POMC messenger and increased formation of ACTH enhanced steroid formation in adrenal cortex, which may also play a role in disruption and protective mucosal layer. Different types of emotional conditions are reported to produce different type of gastric response. Pain, fear and mental depression inhibit gastric secretion and motility of stomach, while anxiety and resentment produced the opposite effect i.e. a large volume of gastric juice of high acidity associated with great engorgement of the mucosa is produced. This effect if is persisted leads to development of erosions and ultimately ulcer. According to Bhargav- central $\alpha, \beta$ - adrenergic and cholinergic muscarinic receptors facilitate stress-induced ulceration, where as GABA and benzodiazepine receptors inhibit stress ulceration. 6-Dopamine and 5hydroxytryptamine do not modulate stress ulcers significantly. It would be interesting to ascertain whether test drug modulate these receptors or not.(17)
Mucosal microcirculation plays important role in prevention of injury to gastro-duodenal mucosa. The main function of the microcirculation is to provide requisite amount of oxygen, nutrients and bicarbonates to surface epithelial cells and removal of $\mathrm{H}^{+}$ion that might get access to mucosal epithelial cells. Any disturbance in the microcirculation will lead to erosion of mucus membrane. Thus disturbance in the microcirculation may be the main factor in stress-induced ulceration. Prostaglandin play important role in the regulating mucosal flow. It is possible that the Test formulations may enhance the formation and turnover of prostaglandins.(18)

From the above discussion it becomes clears that several sites of actions are available to the test formulations to produce its effect. It may intervene at the central level by decreasing the activity of HPA-axis leading to reduced secretion of cortisol. Inhibiting or decreasing formation of POMC during stressful conditions can bring about this effect. Another potential site is to prevent increased acid secretion by the parietal cell by intervening with activities of pro-secretory factor like histamine, gastrin and by inhibiting $\mathrm{H}^{+}, \mathrm{K}^{+}$ AT Pase enzyme through a central action during stressful condition.

\section{Conclusion:}

From the present comparative experimental study it can be concluded that the test formulations showed decrease in body weight compared to initial body weight, they did not affect the rectal temperature to significant extent in comparison to stress control group. An apparent and statistically highly significant decrease in ulcer index was observed in 
both the test formulations treated group in comparison to stress control group. The magnitude of anti-ulcer effect was found to be higher in Narikela Khanda granules treated group.

\section{References:}

1. Konturek S. J, Piastucki I, Brzozowski T, Radecki T, Dembinska-Kiec A, Zmuda A, Role of prostaglandins in the formation of aspirin-induced gastric ulcers. Gastroenterol. September, 1981;80(1);4-9.

2. Goel R. K, Gupta S, Shankar R, Sanyal A. K, Antiulcerogenic effect of Banana powder and its effect on mucosal resistance. J. Ethnopharmacol. October, 1986;18(1);33.

3. Kalsariya B. D, Prajapati P. K, Patgiri B. J, Ravishankar B, Subrata De, A Comparative PharmaceuticoPharmaco-Clinical study of Amalaki Rasayana prepared by freeze dried and ordinary Amalaki w.s.r. to Amlapittahara effect. Jamnagar, I.P.G.T.\& R.A., Gujarat Ayurved University; 2005. 75 p.

4. Shastri A, Bhaishajya Ratnavali. $18^{\text {th }}$ ed. Varanasi, Chaukhambha Sanskrit Sansthana; 2005. 464 p.

5. Paget G. E, Barnes J. M, Toxicity tests. In : Laurence DR Bacharach A.L, editors. Evaluation of drug activities: pharmacometrics. London and New York: Academic Press; 1964. 134-66 p.

6. Hopkins S, Vinkers C. H, Bogaert M. J, Klanker M, Olivier B, Pharmacological research into anxiety disorders: the stress-induced hyperthermia paradigm. Eur. J. Pharmacol. January, 2008;585;407-25.
7. Parmar N. S, Desai J. K, A review of the current methodology for the evaluation of gastric and duodenal antiulcer agents. Indian J. Pharmacol. March, 1993;25;120-35.

8. Sanyal A. K, Pandey B. L, Goel R. K, The effect of a traditional preparation of copper, tamrabhasma, on experimental ulcers and gastric secretion. J. Ethnopharmacol. January, 1982; 5(1);79.

9. Brodie D. A, Hanson H. M, A study of the factors involved in the production of gastric ulcers by restraint techniques. Gastroenterol. March, 1960;38;353-60.

10. Miller L. G, Thompson M. L, Greenblat D. J, Deutsch S. I, Shadder R. I, Paul S. M, Rapid increase in brain benzodiazepine receptor binding following defeat stress in mice. Brain Res. June, 1987;414(2);398-9.

11. Pal S, Nag Chaudhari A. K, Studies on the Anti-ulcer activity of Bryophyllum pinnatum leaf extract in experimental animals. J. Ethnopharmacol. May, 1991;33(1);97-102.

12. Garrick T, Leung F. W, Buack S, Hirabayashi K, Guth P. H, Gastric motility is stimulated but overall blood flow is unaffected during cold restraint in the rat. Gastroenterol. January, 1986;91(1);141-8.

13. Chi H Cho, Clive W. Ogle, Soter Dai, Acute gastric ulcer formation in response to electrical vagal stimulation in rats. Eur. J. Pharmacol. January, 1976;35(1);215-19.

14. Hase T, Moss B. J, Microvascular changes in gastric mucosa in development of gastric ulcers in rats. Gastroenterol.

October, $1973 ; 65(5) ; 224-8$. 
15. Chi H. Cho, Clive W. Ogle, Collinergic mediated gastric mast cell degranulation with subsequent histamine $\mathrm{H} 1$ and $\mathrm{H} 2$ receptor activation in stress ulceration in rats. Eur J. Pharmacol. April, 1979;55(1);23-33.

16. Miller L. G, Thompson M. L, Greenblat D. J, Deutsch S. I, Shadder R. I, Paul S. M, Rapid increase in brain benzodiazepine receptor binding following defeat stress in mice. Brain Res. June, 1987;414(2);397-9.

17. Sahu S, Sharma P. P, Ravishankar B, Pillai A. P. G, Subrata De, A phytochemical and pharamco- therapeutic study of Patola (Trichosanthes dioica Roxb.) in the management of Amlapitta. Jamnagar, I.P.G.T.\& R.A., Gujarat Ayurved University; 2004. 90 p.

18. Sanyal A. K, Pandey B. L, Goel R. K, The effect of a traditional preparation of copper, tamrabhasma, on experimental ulcers and gastric secretion. J. Ethnopharmacol. January, 1982;5(1);79-89. 